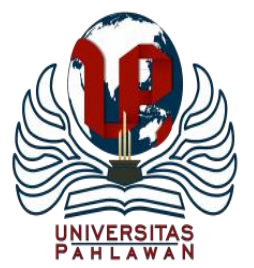

Jurnal Basicedu Volume 4 Nomor 4 Tahun 2020 Halaman 1052-1065

JURNAL BASICEDU

Research \& Learning in Elementary Education

https://jbasic.org/index.php/basicedu

\title{
Implementasi Model ASSURE untuk Mengembangkan Desain Pembelajaran di Sekolah Dasar
}

\author{
Rozie Iskandar ${ }^{1}$, Farida $\mathbf{F}^{2}$ \\ Universitas Negeri Padang, Sumatera Barat, Indonesia ${ }^{1,2}$ \\ E-mail : rozieiskandar@yahoo.com ${ }^{1}$ Faridafachruddin67@ gmail.com ${ }^{2}$
}

\begin{abstract}
Abstrak
Pendidikan merupakan salah satu penentu dalam meningkatkan sumber daya manusia. Guru sebagai pendidik sangat berperan penting dalam hal ini. Salah satu upaya yang dapat dilakukan untuk mewujudkannya yaitu dengan mengembangkan desain pembelajaran agar terciptanya pembelajaran yang efektif dan efisien. Desain pembelajaran yang dikembangkan oleh guru dirancang dengan mengimplementasikan model ASSURE dalam pelaksanaan proses pembelejaran. Model ASSURE merupakan model pembelajaran yang dirancang untuk difokuskan agar terciptanya pembelajaran yang efektif dan efisien khususnya pada kegiatan pembelajaran yang menggunakan media dan tenologi. Selain mengembangkan desain pembelajaran dengan implementasi model ASSURE dalam proses pembelajaran, guru juga menggunakan konsep pembelajaran tematik terpadu. Dimana pembelajaran tematik terpadu ini adalah pembelajaran yang mengaitkan beberapa bidang studi kedalam sebuah tema yang saling terkait untuk memberikan pengalaman yang nyata bagi peserta didik sehingga dapat mengembangkan pengetahuan peserta didik dan meningkatkan hasil belajar bagi peserta didik. Selain itu, juga membantu guru dalam melakukan evaluasi terhadap proses pembelajran yang telah dilaksanakan.
\end{abstract}

Kata kunci : desain pembelajaran, model ASSURE, pembelajaran tematik

\begin{abstract}
Education is one of the determinants in increasing human resources. Teachers as educators play an important role in this matter. One effort that can be done to make it happen is by developing learning designs in order to create effective and efficient learning. The learning design developed by the teacher is designed by implementing the ASSURE model in the implementation of the learning process. The ASSURE model is a learning model that is designed to be focused so that effective and efficient learning is created, especially in learning activities that use media and tenology. In addition to developing the design of learning by implementing the ASSURE model in the learning process, the teacher also uses the concept of integrated thematic learning. Where integrated thematic learning is learning that links several fields of study into an interrelated theme to provide tangible experiences for students so that they can develop students' knowledge and improve learning outcomes for students. In addition, it also helps the teacher in evaluating the learning process that has been carried out.
\end{abstract}

Keyword : learning design, ASSURE model, thematic learning

Copyright (c) 2020 Rozie Iskandar, Farida F

$\triangle$ Corresponding author

Address : Universitas Negeri Padang

Email : rozieiskandar@yahoo.com

ISSN 2580-3735 (Media Cetak)

Phone :-

ISSN 2580-1147 (Media Online)

DOI: https://doi.org/10.31004/basicedu.v4i4.468 
1053 Implementasi Model ASSURE Untuk Mengembangkan Desain Pembelajaran di Sekolah Dasar Rozie Iskandar, Farida F

DOI: https://doi.org/10.31004/basicedu.v4i4.468

\section{PENDAHULUAN}

Pendidikan merupakan salah satu faktor penentu dalam upaya meningkatkan kualitas sumber daya manusia. Pendidikan dapat dijadikan tolak ukur dalam menentukan kualitas pribadi seseorang dan kemajuan suatu bangsa. Oleh sebab itu pemerintah, melalui Menteri Pendidikan dan Kebudayan mengeluarkan peraturan yang tertuang dalam Permendikbud Nomor 21-24 tahun 2016 untuk jenjang pendidikan dasar.

Permendikbud No 22 Tahun 2016 mengamanatkan bahwa proses pembelajaran pada satuan pendidikan harus diselenggarakan secara interaktif, inspiratif, menyenangkan, menantang, memotivasi peserta didik untuk berpatisipasi aktif serta memberikan ruang yang cukup bagi kreativitas, kemandirian sesuai bakat, minat serta perkembangan peserta didik. Pada proses penerapan pelaksanaan pembelajaran setiap satuan pendidikan dituntut untuk mampu melakukan perencanaan pembelajaran dengan baik, sehingga pelaksanaan proses pembelajaran dapat berjalan semaksimal mungkin serta penilaian proses pembelajaran bisa diarahkan untuk meningkatkan efesiensi dan efektifitas ketercapaian kompetensi lulusan.

Menurut Nofriza, Yanti Fitria, Farida dan Syahniar (2019) dalam pembelajaran hendaknya seorang guru mampu menggunakan pendekatan pembelajaran yang cocok untuk meningkatkan partisipasi belajar siswa. Pendekatan atau model pembelajaran yang akan digunakan oleh guru akan berdampak bagi proses pembelajaran, dengan adanya penggunaan pendekatan yang cocok. Salah satu pendekatan yang mampu meningkatkan partisipasi belajar peserta didik.
Kurikulum yang berlaku menjadi panutan dalam pendidikan. Menurut Lifda, Taufina dan Farida (2020) Kurikulum 2013 pada kelas tinggi menuntut perencanaan dan pelaksanaan pembelajaran menggunakan model pengintegrasian sehingga model integrasinya adalah multidisipilinear walaupun pembelajarannya tetap menggunakan tematik terpadu. Dimana mata pelajaran yang terkait diintegrasikan kedalam sebuah tema yang menjadi penyatu dalam materi pembelajarannya. Kemampuan peserta didik juga menjadi acuan dalam hal ini.

Menurut Fitriyanti, Farida dan Ahmad Zikri (2020), Kemampuan dasar yang dimiliki oleh peserta didik setelah terlaksananya suatu pembelajaran dapat diukur pada aspek kognitif, afektif dan psikomotor dari peserta didik setelah terjadinya proses pembelajaran. Kemampuan ini menjadi salah satu wujud pendidikan yang harus dicapai dalam tujuan pendidikan.

Untuk dapat mewujudkan tujuan pendidikan yang tertuang maka guru harus dapat mengakomodasi tuntutan dari standar isi dan standar proses tersebut. Salah satu cara yang dapat dilakukan untuk mengakomodasi tuntutan dari standar isi dan standar proses adalah dengan mendesain pembelajaran.

Desain pembelajaran merupakan suatu rangkaian untuk menciptakan proses pembelajaran dengan baik, benar dan menyenangkan. Menurut Sanjaya (2012:67) desain pembelajaran berkenaan dengan proses penentuan tujuan pembelajaran, strategi pembelajaran dan teknik untuk mencapai tujuan serta merancang media yang dapat digunakan untuk mencapai efektifitas pembelajaran. 
1054 Implementasi Model ASSURE Untuk Mengembangkan Desain Pembelajaran di Sekolah Dasar Rozie Iskandar, Farida F

DOI: https://doi.org/10.31004/basicedu.v4i4.468

Pengembangan desain pembelajaran adalah teknik pengelolaan dalam mencari pemecahan masalahmasalah pembelajaran sehingga dapat mengoptimalkan pemanfatan sumber belajar untuk memperbaiki hasil belajar

Desain pembelajaran berakar pada psikologi kognitif dan prilaku peserta didik yang dapat dilihat dari sudut pandang sebagai ilmu yang merupakan pengetahuan untuk menciptakan spesifikasi pengembangan, pelaksanaan, penilaian serta pengelolaan. Situasi yang memberikan fasilitas layanan pembelajaran dalam skala mikro untuk berbagai mata pelajaran pada tingkatan kompleksitas. Guru harus mengenal bagaimana karakteristik peserta didik serta menyusun sistem pembelajaran atas dasar keadaan peserta didik.

Salah satu model yang digunakan untuk mendesain pembelajaran secara sistematis dan menyeluruh yang berorientasi kepada pemanfaatan media dan teknologi dalam menciptakan sebuah pembelajaran yang efektif, efesien dan menarik adalah desain pembelajaran dengan menggunakan model ASSURE Desain pembelajaran dengan menggunakan model ASSURE adalah salah satu desain pembelajaran yang bisa membantu untuk merencanakan, mengidentifikasi, menentukan tujuan, memilih model dan bahan serta evaluasi yang tepat. Model ASSURE merupakan singkatan dari komponen atau langkah penting yang terdapat di dalamnya. Desain pembelajaran dengan menggunakan model ASSURE ini merupakan rujukan bagi pendidik dalam aktivitas pembelajaran yang direncanakan dan disusun secara sistematis dengan mengintegrasikan teknologi dan media sehingga pembelajaran menjadi lebih efektif dan bermakna. Pembelajaran yang bermakna akan merujuk pada pembelajaran yang efektif, efisien dan menarik.

Menurut Ratumanan (2002:52) dengan belajar yang bermakna, informasi disusun sesuai dengan struktur kognitif peserta didik sehingga peserta didik dapat mengaitkan pengetahuan baru tersebut dengan struktur kognitifnya. Dengan demikian, informasi atau pengetahuan yang diperoleh selama proses pembelajaran dapat menjadi suatu memori jangka panjang dalam diri peserta didik.

Pemilihan model ASSURE dalam pengembangan desain pembelajaran karena dengan menggunakan model ASSURE guru dapat mengkaji karakteristik peserta didik sebelum belajar, kemudian menetapkan tujuan pembelajaran yang akan dicapai, menyeleksi media, model dan materi yang akan digunakan dalam proses pembelajaran serta melakukan evaluasi dan revisi yang sesuai dengan aktivitas pembelajaran yang telah dilakukan. Dengan menggunakan model ASSURE guru dapat mengidentifikasi karakteristik peserta didik yang akan melakukan aktivitas pembelajaran dan dapat membantu peserta didik dalam upaya mencapai tujuan pembelajaran.

Pemilihan metode, media dan materi yang tepat akan mampu mengoptimalkan hasil belajar peserta didik dan membantu peserta didik mencapai kompetensi atau tujuan pembelajaran. Dalam pemilihan metode, media dan materi yang menarik dapat menciptakan tercipta aktivitas pembelajaran menjadi efektif, efisien dan menyenangkan. Pada tahap evaluasi dan revisi dalam desain pembelajaran ini dilakukan untuk menilai efektivitas pembelajaran dan juga hasil belajar peserta didik, sehingga 
1055 Implementasi Model ASSURE Untuk Mengembangkan Desain Pembelajaran di Sekolah Dasar Rozie Iskandar, Farida F

DOI: https://doi.org/10.31004/basicedu.v4i4.468

memperoleh gambaran lengkap tentang kualitas sebuah program pembelajaran.

Dengan mendesain pembelajaran menggunakan model ASSURE diharapkan proses pembelajaran dapat berjalan dengan efektif dan bermakna sesuai dengan tuntutan kurikulum. Desain pembelajaran merupakan proses merancang program pembelajaran untuk membantu proses belajar peserta didik. Martinis (2007:10) Benny (2010 : 96) Ratumanan (2002:52) mengemukakan desain pembelajaran adalah tata cara yang dipakai untuk melaksanakan preses pembelajaran. Benny (2010 : 96) menyatakan desain pembelajaran merupakan sarana konseptual untuk menganalisis, merancang, memproduksi, menerapkan dan mengevaluasi sebuah aktivitas atau program pembelajaran.

Pendapat lebih lanjut dikemukakan oleh Herbert Simon (dalam Wina 2011:65) yang menyatakan desain pembelajaran merupakan suatu proses yang bersifat linier untuk pemecahan masalah yang diawali dengan penentuan kebutuhan, kemudian mengembangkan rancangan untuk merespon kebutuhan tersebut, diujicobakan dan akhirnya dilakukan proses evaluasi untuk menentukan hasil tentang efektivitas desain/rancangan yang disusun. Gagne (dalam Wina, 2008:66) menjelaskan bahwa desain pembelajaran disusun untuk membantu proses belajar peserta didik, yang memiliki tahapan segera dan tahapan jangka panjang.

Smith dan Ragan's (2007:10) dalam (dalam Putrawangsa, 2018: 21) mengemukakan bahwa, desain pembelajaran itu adalah "the systemic and reflective process of translating principles of learning and instruction into plans for instructional materials, activities, information resources, and evaluation". Dalam definisi ini, Smith dan Ragan's menegaskan bahwa desain pembelajaran adalah proses yang sistematis dan reflektif dalam menerjemahkan prinsip-prinsip belajar dan pembelajaran ke dalam bentuk suatu perencanaan yang digunakan sebagai materi pembelajaran, kegiatan pembelajaran, sumber belajar, dan evaluasi pembelajaran

Menurut Wina (2011:80) desain pembelajaran dapat dimaknai sebagai sudut pandang, misalnya sebagai disiplin, sebagai ilmu, sebagai sistem dan sebagai proses. Sebagai disiplin, desain pembelajaran membahas penelitian dan teori tentang stategi serta proses pengembangan pembelajaran dan pelaksanannya. Sebagai ilmu, desain pembelajaran merupakan ilmu untuk menciptakan spesifikasi pengembangan, pelaksanaan, penilaian serta pengelolaan situasi yang memberikan fasilitas pelayanan pembelajaran dalam skala makro dan mikro untuk berbagai mata pelajaran pada berbagai tingkatan kompleksitas. Sebagai sistem, desain pembelajaran merupakan gabungan pengembangan sistem pembelajaran dan sistem pelaksanannya termasuk sarana serta prosedur untuk meningkatkan mutu belajar.

Pada kemajuan teknologi dan pengetahuan, seorang guru tidak hanya dituntut untuk menyampaikan informasi, guru juga dituntut untuk dapat membuat persiapan mengajar dengan baik. Persiapan mengajar yang disiapkan dapat disusun menjadi rancangan instruksional. Keterpaduan antar komponen dalam pembuatan persiapan mengajar dapat mewujukan tercapainya tujuan instruksional 
1056 Implementasi Model ASSURE Untuk Mengembangkan Desain Pembelajaran di Sekolah Dasar Rozie Iskandar, Farida F

DOI: https://doi.org/10.31004/basicedu.v4i4.468

secara efesien dan efektif (Roro \& Wahyulestari, 2012).

Berdasarkan pendapat di atas dapat disimpulkan bahwa desain pembelajaran adalah tata cara yang dipakai untuk melaksanakan proses pembelajaran dan untuk pemecahan masalah pembelajaran yang diawali dengan penentuan kebutuhan, kemudian mengembangkan rancangan untuk merespon kebutuhan tersebut, diujicobakan dan akhirnya dilakukan proses evaluasi untuk menentukan hasil tentang efektivitas desain atau rancangan yang disusun.

Desain pembelajaran dengan menggunakan model ASSURE dikembangkan untuk menciptakan aktivitas pembelajaran yang efektif dan efesien. Desain pembelajaran model ASSURE dirancang untuk membantu para guru merencanakan materi pelajaran yang secara efektif memadukan penggunaan teknologi dan media di ruang kelas (Sharon, 2011:111).

Yavus (2015:28) mengemukakan bahwa "ASSURE instructional design modelis, one of the various design models, used for Instructional Design. ASSURE model is preferred in media and technology integrated instructions. In addition to being organized, it is a strategy and idea to assist instructor on designing and evaluation of the instruction. Model ASSURE merupakan salah satu model yang dapat digunakan untuk desain instruksional karena model ASSURE mengintegrasikan media dan teknologi untuk membantu guru dalam merancang evaluasi.

Sejalan dengan pendapat di atas, desain pembelajaran model ASSURE merupakan sebuah formulasi untuk kegiatan belajar mengajar (KBM) atau model berorientasi kelas, desain pembelajaran model ASSURE lebih difokuskan pada perencanaan pembelajaran untuk digunakan dalam situasi pembelajaran di dalam kelas secara aktual (Husamah, 201 : 58) ( Reza, 2016 : 45). Desain pembelajaran model ASSURE adalah salah satu petunjuk dan perencanaan yang bisa membantu untuk bagaimana cara merencanakan, mengidentifikasi, menentukan tujuan, memilih model dan bahan, serta evaluasi (Husamah, 201 : $58)$.

Berdasarkan beberapa pandangan para ahli mengenai pengertian desain pembelajaran model ASSURE, dapat disimpulkan bahwa desain pembelajaran dengan menggunakan model ASSURE merupakan sebuah desain pembelajaran yang dirancang untuk difokuskan pada perencanaan pembelajaran agar terciptanya aktivitas pembelajaran yang efektif dan efisien, khususnya pada kegiatan pembelajaran yang menggunakan media dan tekhnologi. ASSURE merupakan singkatan dari komponen atau langkah penting yang terdapat di dalamnya. Model ini adalah urutan operasi yang dikembangkan untuk perencanaan penggunaan teknologi yang membantu guru merancang dan meningkatkan kegiatan pembelajaran.

Dalam pelaksanaannya desain pembelajaran model ASSURE terdiri dari enam langkah antara lain : (1) mengalisis pembelajar, (2) menentukan standar dan tujuan, (3) memilih metode, media dan materi, (4) menggunakan metode, media, dan materi, (5) partisipasi pembelajar, dan (6) mengevaluasi dan merevisi, (Smaldino, 2011:110). 
1057 Implementasi Model ASSURE Untuk Mengembangkan Desain Pembelajaran di Sekolah Dasar Rozie Iskandar, Farida F

DOI: https://doi.org/10.31004/basicedu.v4i4.468

Menurut Theodorio (2018:2) langkah-langkah Model ASSURE adalah sebagai berikut :1) Analyze learners: Planning for audience and their characteristics (e.g. age, sex,socio-economic background, mental readiness and learning styles).2) State objectives: Tutors are encouraged to consider the class of audience, theirbehaviors and the type of degree they are studying for. 3) Select technology/media/material: Select from material pool or modify or create a new one. 4)Utilize the material: Preview the material and text the material/media or technology. 5)Requires learners' participation: Bring learners in to harvest their views and advise. 6) Evaluate the media/technology with stated learning objectives.

Langkah pertama dari desain pembelajaran model ASSURE adalah analisis peserta didik. Langkah kedua adalah menyatakan tujuan. Tujuan digunakan untuk menentukan informasi dan keterampilan apa yang diperoleh pada akhir pembelajaran. Langkah ketiga adalah memilih metode media serta untuk mencapai tujuan yang didefinisikan pada langkah sebelumnya. Langkah keempat adalah menggunakan metode, media dan materi pada langkah sebelumnya secara efektif dan produktif. Langkah kelima adalah partisipasi peserta didik sehingga peserta didik mendapat manfaat dari kegiatan pembelaajran yang telah dilakukan. Langkah terakhir dari model ini adalah untuk mengevaluasi semua komponen pembelajaran sehingga mencapai hasil belajar yang berkualitas.

Sejalan dengan pendapat di atas, langkahlangkah penting yang perlu dilakukan dalam desain pembelaajran model ASSURE meliputi beberapa aktivitas, yaitu (1) melakukan analisis karakteristik peserta didik (analyze learners), (2) menetapkan tujuan pembelajaran (state objectives), (3) memilih strategi, teknologi, metode pembelajaran, dan materi (select metods, media, and material), memanfaatkan strategi, teknologi, media dan materi (utilize materials), (5) melibatkan peserta didik dalam kegiatan pembelajaran (require learners participation), dan (6) mengevaluasi dan merevisi program pembelajaran (evaluated and revise) (Benny (2010:112).

Berdasarkan beberapa pendapat para ahli mengenai langkah-langkah desain pembelajaran dengan menggunakan model ASSURE, peneliti menerapkan langkah yang dikemukakan oleh Smaldino (2011:110) yaitu: (1) mengalisis pembelajar, (2) menentukan tujuan, (3) memilih model, media dan materi, (4) menggunakan model, media, dan material, (5) mengharuskan partisipasi pembelajar, dan (6) mengevaluasi dan merevisi.

Secara lanjut langkah-langkah desain pembelajaran menggunakan model ASSURE dijelaskan sebagai berikut:

1) Menganalisis pembelajar. Langkah awal yang perlu dilakukan dalam pengembangan desain pemmbelajaran menggunakan model ASSURE adalah mengidentifikasi karakteristik siswa yang akan melakukan aktivitas pembelajaran. Pemahaman yang baik tentang karakteristik siswa akan sangat membantu siswa dalam mencapai tujuan pembelajaran. Analisis terhadap karakteristik siswa meliputi beberapa hal penting seperti karakteristik umum, kompetensi, dan gaya belajar.

2) Menetapkan tujuan pembelajaran. Langkah selanjutnya dari desain pembelajaran 
menggunakan model ASSURE adalah menetapkan tujuan pembelajaran yang bersifat spesifik. Tujuan pembelajaran merupakan rumusan pernyataan yang mendeskripsikan tentang kompetensi yang diperoleh siswa setelah menempuh proses pembelajaran.

3) Memilih metode, media dan materi. Setelah menganalisis pembelajar dan menetapkan tujuan maka langkah berikutnya yaitu memilih metode, media dan materi Pemilihan materi yang sesuai dengan tujuan pembelajaran, dilanjutkan dengan memilih metoda yang sesuai untuk melaksanakan kegiatan pembelajaran, dan langkah terakhir adalah memilih dan atau mendesain media yang mendukung terlaksananya kegiatan pembelajaran.

4) Penggunaan metode, media dan materi. Setelah memilih metode, media dan materi langkah selanjutnya adalah menggunakan ketiganya dalam kegiatan pembelajaran. Sebelum menggunakan metode, media dan materi, pendidik harus menyiapkan kelas dan sarana pendukung yang diperlukan untuk dapat menggunakanya.

5) Partisipasi pembelajar. Proses pembelajaran memerlukan keterlibatan peserta didik secara aktif dengan materi yang sedang dipelajari. Partisipasi pembelajar akan tampak dari adanya umpan balik dari siswa.

6) Evaluasi dan revisi. Setelah mendesain kegiatan pembelajaran maka langkah selanjutnya adalah evaluasi. Pada tahap evaluasi dalam model ASSURE dilakukan untuk menilai efektifitas dan praktikalitas desain pembelajaran. Proses evaluasi terhadap semua komponen pembelajaran perlu dilakukan agar dapat memperoleh gambaran yang lengkap tentang kualitas sebuah program.

Pembelajaran tematik terpadu sebagai suatu konsep dapat dikatakan sebagai suatu pendekatan belajar mengajar yang melibatkan beberapa bidang studi untuk memberikan pengalaman bermakna kepada peserta didik. Pembelajaran yang berbasis tema merupakan pembelajaran yang dirancang berdasarkan tema-tema tertentu yang ditinjau dari berbagai mata pelajaran yang terkait (Abdul, 2014:123).

Pada pembelajaran tematik terpadu, pembelajaran menggunakan tema tertentu, guna mengaitkan beberapa isi mata pelajaran dengan pengalaman kehidupan nyata sehari-hari peserta didik sehingga memberikan pengalaman yang bermakna bagi peserta didik (Trianto, 2010: 82). Pembelajaran terpadu dilaksanakan dengan menggunakan tema sebagai pemersatu kegiatan pembelajaran yang memadukan beberapa mata pelajaran sekaligus dalam satu kali tatap muka (Irwantoro 2016:186).

Berdasarkan beberapa pendapat ahli yang telah dipaparkan dapat disimpulkan pengertian dari tematik terpadu adalah pembelajaran yang dirancang berdasarkan tema-tema tertentu, untuk mengaitkan antara beberapa isi mata pelajaran dengan pengalaman kehidupan nyata sehari-hari peserta didik sehingga dapat memberikan pengalaman bermakna bagi peserta didik.

Tematik terpadu lebih menekankan kepada penerapan konsep belajar sambil melakukan sesuatu. Dengan pembelajaran tematik terpadu, peserta didik 
dapat memperoleh pengalaman langsung dan berlatih menemukan sendiri berbagai pengetahuan yang dipelajarinya secara holistik, autentik, dan aktif. Beberapa tujuan pembelajaran tematik terpadu adalah menggabungkan beberapa kompetensi dasar dan indikator serta isi mata pelajaran, maka akan terjadi penghematan, sehingga peserta didik mampu melihat hubungan-hubungan yang bermakna setiap pembelajaran, proses pembelajaran materi tidak terpecah-pecah dan dapat meningkatkan penguasaaan konsep pada peserta didik ( Trianto 2010: 87).

Tujuan pembelajaran tematik terpadu adalah sebagai berikut, (1) mudah memusatkan perhatian pada satu tema atau topik tertentu, (2) mengembagkan berbagai kompetensi mata pelajaran dalam tema yang sama, (3) pemahaman terhadap materi pelajaran lebih mendalam dan berkesan, (4) mengkaitkan berbagai mata pelajaran lain dengan pengalaman pribadi peserta didik, (5) lebih bergairah belajar karena mereka dapat berkomunikasi dalam situasi nyata, (6) lebih merasakan manfaat dan makna belajar karena materi yang disajikan dalam konteks tema yang jelas, (7) guru dapat menghemat waktu, (8) budi pekerti dan moral peserta didik dapat ditumbuh kembangkan dengan mengangkat sejumlah nilai budi pekerti sesuai dengan situasi dan kondisi (Kemendikbud 2014:27).

Pembelajaran tematik terpadu dilakukan agar memudahkan peserta didik memusatkan perhatian pada tema tertentu, mempelajari pengetahuan dan mengembangkan berbagai kompetensi mata pelajaran dalam tema yang sama. Pembelajaran tematik terpadu juga dapat digunakan untuk mengembangkan kompetensi berbahasa lebih baik karena dapat mengaitkan berbagai mata pelajaran lain dengan pengalaman pribadi peserta didik. Guru dapat menghemat waktu karena mata pelajaran yang disajikan secara terpadu dapat disiapkan sekaligus. Budi pekerti dan moral peserta didik dapat ditumbuh kembangkan dengan menganggkat sejumlah nilai budi pekerti sesuai dengan situasi dan kondisi (Irwantoro 2016:186).

Pengajaran yang efektif adalah pengajaran yang menyediakan kesempatan belajar sendiri atau melakukan aktivitas sendiri, artinya peserta didik belajar sambil bekerja. Dengan demikian, mereka memperoleh pengetahuan pemahaman, dan aspekaspek tingkah laku lainnya. Menurut Hamalik, (2012:171), aktivitas adalah perbuatan-perbuatan yang dilakukan, termasuk perbuatan belajar dan bekerja, dimaksud untuk memuaskan perbuatan tertentu untuk mencapai tujuan tertentu pula. Asas aktivitas digunakan dalam semua jenis metode mengajar, baik metode dalam kelas maupun metode mengajar di luar kelas. Hanya saja penggunaannya dilaksanakan dalam bentuk permainan sesuai dengan tujuan yang hendak dicapai dan disesuaikan pula pada orientasi sekolah yang menggunakan jenis kegiatan itu.

Menurut Sutrisno (2012:84) aktivitas adalah suatu rangkaian kegiatan dalam proses pembelajaran. Paul D. Dierich dalam Sardiman (2011) berpendapat aktivitas dalam pembelajaran dibagi menjadi delapan kelompok yaitu

\section{1) Visual Activities}

Kegiatan belajar yang termasuk aktivitas visual diantaranya, membaca, memperhatikan gambar, demonstrasi, dan percobaan. 
1060 Implementasi Model ASSURE Untuk Mengembangkan Desain Pembelajaran di Sekolah Dasar Rozie Iskandar, Farida F

DOI: https://doi.org/10.31004/basicedu.v4i4.468

2) Oral Activities

Kegiatan di kelas yang dapat diklasifikasikan dalam aktivitas lisan yaitu memberi saran, mengeluarkan pendapat, mengadakan wawancara, diskusi, bertanya, presentasi dan lain-lain.

\section{3) Listening Activities}

Aktivitas mendengarkan dalam belajar meliputi mendengarkan percakapan, mendengarkan diskusi, mendengarkan presentasi, mendengar pertanyaan teman di kelas atau di kelompok dan lain-lain.

4) Writing Activities

Siswa yang menulis laporan, membuat tabel, mencatat, dan menyalin termasuk dalam klasifikasi aktivitas menulis.

5) Drawing Activities

Kegiatan menggambar meliputi menggambar grafik, menggambar peta, menggambar diagram dan lain-lain.

6) Motor Activities

Kegiatan yang termasuk aktivitas gerak diantaranya adalah melakukan percobaan, membuat konstruksi/model, dan mengukur.

7) Mental Activities

Kegiatan mental dalam belajar diantaranya yaitu menanggapi, mengingat, memecahkan soal, menganalisis, melihat hubungan, mengambil keputusan, melengkapi tabel, melengkapi gambar dan lain-lain.

8) Emotional Activities

Kegiatan seperti menaruh minat, bersemangat, berani, antusias dan tenang merupakan contoh aktivitas emosional.
Dari klasifikasi aktivitas peserta didik di atas menunjukkan bahwa aktivitas peserta didik dalam pembelajaran cukup kompleks dan bervariasi. Semakin bervariasi aktivitas peserta didik yang diciptakan maka proses pembelajaran semakin efektif dan menjadi pusat aktivitas pembelajaran yang maksimal.

Hasil belajar adalah suatu hasil nyata yang dicapai oleh peserta didik dalam usaha menguasai kecakapan jasmani dan rohani di sekolah yang diwujudkan dalam bentuk rapor pada setiap semester. Suprijono (2010:5) menyatakan hasil belajar adalah pola-pola perbuatan, nilai-nilai, pengertian-pengertian, sikap-sikap, apresiasi dan keterampilan. Selanjutnya menurut Sudjana (2012:22) menyatakan bahwa hasil belajar adalah kemampuan-kemampuan yang dimiliki peserta didik setelah ia menerima pengalaman belajarnya

Berdasarkan pendapat dari beberapa ahli tersebut, secara sederhana, dapat disimpulkan yang dimaksud dengan hasil belajar peserta didik adalah kemampuan yang diperoleh peserta didik setelah melalui kegiatan mengajar.

\section{METODE}

Pemilihan model desain pengembangan yang baik akan menghasilkan produk yang efektif dan efesien. Ketepatan pemilihan model desain pengembangan akan menghasilkan produk yang efektif dan efesien. Ketepatan produk pengembangan yaitu produk yang dapat diaplikasikan dengan baik dan memberi manfaat bagi penggunanya. Hasil produk pengembangan yang baik akan meningkatkan aktivitas belajar peserta didik untuk memperoleh pengalaman belajar 
1061 Implementasi Model ASSURE Untuk Mengembangkan Desain Pembelajaran di Sekolah Dasar Rozie Iskandar, Farida F

DOI: https://doi.org/10.31004/basicedu.v4i4.468

yang menarik. Hasil produk pengembangan desain pembelajaran tematik berupa rencana pelaksanaan pembelajaran (RPP).

Salah satu desain pembelajaran yang berorientasi kelas adalah desain pembelajaran model ASSURE. Prosedur pengembangan pada penelitian ini mengacu pada desain pembelajaran model ASSURE yang dikembangkan oleh Sharon. E. Smaldino, dkk (2005). Model ASSURE terdiri dari 6 langkah yaitu menganalisis pembelajar (analyze learners), menyatakan tujuan (state objective), memilih metode, media dan materi (select method, media, and material), penggunaan media dan materi (utilize media and materials), partisipasi pembelajar (require learner participation), mengevaluasi dan merevisi (Evaluation and revise.) Sharon E Smaldino, dkk (2005).

Penelitian ini memiliki 6 tahapan yaitu menganalisis pembelajar (analyze learners), menyatakan tujuan (state objective), memilih metode, media dan materi (select method, media, and material), penggunaan media dan materi (utilize media and materials), partisipasi pembelajar (require learner participation), mengevaluasi dan merevisi (evaluation and revise.).

Pada tahap analiyze learner characteristich (analisis karakteristik) terdiri dari analisis karakter umum, kompetensi dan gaya belajar peserta didik. Tahap kedua menentukan tujuan (state objective) dan pemilihan metode, media dan bahan ajar (select method, media and materials). Pada tahap penggunaan dari ketiga pemilihan metode, media dan bahan ajar (utileze material) diharuskan adanya partisipasi peserta didik (require learner participation) selanjutnya tahap evaluasi dan revisi dari produk (evaluate dan revisi). Berikut prosedur pengembangan desain pembelajaran perangkat pembelajaran tematik menggunakan desain pembelajran model ASSURE untuk meningkatkan aktivitas pembelajaraan peserta didik di kelas V SD.

\section{HASIL DAN PEMBAHASAN}

Kemajuan teknologi menuntut guru untuk dapat mengembangkan kreatifitasnya dalam menciptakan suasana pembelajaran yang efektif. Pembelajaran yang efektif akan tercipta dengan memanfaat media, sumber dan sarana prasarana yang terbaru untuk daoat terus mengikuti perkembangan pendidikan di dunia. Perkembangan pendidikan sangat pesat, untuk itu guru juga harus mampu untuk bersaing dalam menciptakan suasana pembelajaran yang efektif.

Pada hasil observasi yang dilakukan di sekolah dasar, guru telah menggunakan media yang cukup bagus dalam proses pembelajaran yang dilaksanakannya. Namun, agar suasana belajar semakin digemari oleh peserta didik guru harus memperbaharui semua sumber belajar yang menunjang proses pembelajaran tersebut. Salah satunya dengan membuat sebuah desain pembelajaran.

Desain pembelajaran merupakan suatu proses menyusun, menata dan merancang program pembelajaran sebagus mungkin untuk menumbuhkan ketertarikan peserta didik yang tinggi dalam proses pembelajaran. Desain pembelajaran disusun, ditata dan dirancang semenarik mungkin sehingga tercipta suasana belajar yang menyenangkan bagi peserta didik. 
1062 Implementasi Model ASSURE Untuk Mengembangkan Desain Pembelajaran di Sekolah Dasar Rozie Iskandar, Farida F

DOI: https://doi.org/10.31004/basicedu.v4i4.468

Guru dalam hal ini menadi penentu yang sangat penting dalam menciptakan suasana pembelajaran yang menarik bagi peserta didik. Kekreatifan guru menjadi penentu dalam terciptanya suasana belajar tersebut. Sehingga bermuara kepada hasil belajar peserta didik. Dalam desain pembelajaran yang ditata, disusun dan dirancang oleh guru tentunya dengan menggunakan sebuah model pembelajaran. Model pembelajaran diimplementasikan sesuai dengan keterkaitan materi pembelajaran yang akan diajarkan guru kepada peserta didik.

Salah satu model pembelajaran yang akan diimplementasikan seiring dengan desain yang dirancang oleh guru adalah model ASSURE. Model ASSURE dipilih karena model ini adalah model yang diformulasikan untuk kegiatan belajar mengajar atau disebut juga dengan model yang berorientasi kelas.

Model ASSURE merupakan model yang dirancang untuk membantu guru dalam merancang materi pembelajaran secara efektif dan efisien dengan menggunakan bantua media dan teknologi terkini didalam ruang kelas. selain membantu guru dalam merancang materi pembelajaran yang efektif dan efisien, model ini juga membantu guru untuk melakukan evaluasi terhadap pembelajaran yang dilakukan.

Pada pelaksanaanya model ASSURE memiliki beberapa langkah kegiatan yang dilakukan. Langkah pertama dari desain pembelajaran model ASSURE adalah analisis peserta didik. Pada langkah pertama ini, guru mengalisis peserta didiknya terlebih dahulu. Analisis peserta didik disini maksudnya adalah guru sebagai pendidik harus memiliki pemahaman yang baik tentang karakteristik peserta didik yang dapat membantu peserta didik dalam mencapai tujuan pembelajaran. Analisis terhadap karakteristik peserta didik meliputi beberapa hal penting seperti karakteristik umum, kompetensi, dan gaya belajar peserta didik.

Langkah kedua adalah menyatakan tujuan. Tujuan pembelajaran merupakan rumusan pernyataan yang mendeskripsikan tentang kompetensi yang diperoleh siswa setelah menempuh proses pembelajaran. Tujuan digunakan untuk menentukan informasi dan keterampilan apa yang diperoleh pada akhir pembelajaran.

Langkah ketiga adalah memilih metode media serta untuk mencapai tujuan yang didefinisikan pada langkah sebelumnya. Setelah menganalisis pembelajar dan menetapkan tujuan maka langkah berikutnya yaitu memilih metode, media dan materi Pemilihan materi yang sesuai dengan tujuan pembelajaran, dilanjutkan dengan memilih metoda yang sesuai untuk melaksanakan kegiatan pembelajaran, dan langkah terakhir adalah memilih dan atau mendesain media yang mendukung terlaksananya kegiatan pembelajaran.

Langkah keempat adalah menggunakan metode, media dan materi pada langkah sebelumnya secara efektif dan produktif. Setelah memilih metode, media dan materi langkah selanjutnya adalah menggunakan ketiganya dalam kegiatan pembelajaran. Sebelum menggunakan metode, media dan materi, pendidik harus menyiapkan kelas dan sarana pendukung yang diperlukan untuk dapat menggunakanya.

Langkah kelima adalah partisipasi peserta didik sehingga peserta didik mendapat manfaat dari 
1063 Implementasi Model ASSURE Untuk Mengembangkan Desain Pembelajaran di Sekolah Dasar Rozie Iskandar, Farida $F$

DOI: https://doi.org/10.31004/basicedu.v4i4.468

kegiatan pembelaajran yang telah dilakukan.Proses pembelajaran memerlukan keterlibatan peserta didik secara aktif dengan materi yang sedang dipelajari. Partisipasi pembelajar akan tampak dari adanya umpan balik dari siswa

Langkah terakhir dari model ini adalah untuk mengevaluasi semua komponen pembelajaran sehingga mencapai hasil belajar yang berkualitas. Setelah mendesain kegiatan pembelajaran maka langkah selanjutnya adalah evaluasi. Pada tahap evaluasi dalam model ASSURE dilakukan untuk menilai efektifitas dan praktikalitas desain pembelajaran. Proses evaluasi terhadap semua komponen pembelajaran perlu dilakukan agar dapat memperoleh gambaran yang lengkap tentang kualitas sebuah program.

Pembuatan desain pembelajaran dengan mengimplementasikan model ASSURE dalam pelaksanaan pembelajaran mampu menumbuhkan suasana belajar yang efektif dan efisien. Selain itu, dengan implementasi model ASSURE ini juga memberikan kesan yang dirasakan oleh peserta didik dalam proses pembelajaran. Kesan tersebut tentunya memberikan pengalaman tersendiri bagi peserta didik.

Selain merancang desain pembelajaran dengan mengimplementasikan model ASSURE, guru juga merancang konsep pembelajaran tematik terpadu dalam proses pembelajaran. Pembelajaran tematik terpadu ini merupakan pembelajaran yang melibatkan beberapa bidang studi untuk memberikan pengalaman yang bermakna kepada peserta didik.

Pembelajaran tematik terpadu ini merupakan pembelajaran yang berbasis tema dan dirancang oleh guru untuk mengaitkan materi-materi yang berkaitan antara satu bidang studi dengan bidang studi lainnya. Sehingga dalam proses pembelajaran, peserta didik tidak hanya mempelajari satu bidang studi saja ,namun bidang studi tersebut dikaitkan dalam sebuat tema yang menjadi dasar dalam pengembangan materi pembelajaran.

Desain pembelajaran yang dirancang oleh guru dengan menggunakan model ASSURE yang berkonsep pembelajaran tematik terpadu dapat menciptakan suasana belajar yang efektif dan efisien sehingga dalam proses pembelajaran memberikan makna yang sangat berkesan kepada peserta didik. Selain kesan, peserta didik juga mendapatkan pengalaman yang nyata dalam proses pembelajan. Sehingga hasil belajar peserta didik juga meningkat

\section{KESIMPULAN}

Proses pembelajaran yang efektif dan efisien dapat tercipta melalui rancangan program pembelajaran yang dibuat guru dengan penuh inovasi dan kreatifitas yang tinggi. Proses pembelajaran merupakan sebuah proses yang mampu menumbuh kembangkan pengetahuan peserta didik dan memberikan pengalaman yang nyata bagi peserta didik. Sehingga dalam kegiatan proses pembelajaran itu terjadi peserta didik dapat merasakan pengalaman tersebut bagi dirinya sendiri. Baik itu langsung maupun tidak langsung terhadap dirinya dalam proses pembelajaran.

Salah satu cara dalam menciptakan proses pembelajaran yang efektif dan efisien adalah dengan mendesain pembelajaran dengan mengimplementasikan model serta menggunakan konsep pembelajaran yang akan dilakukan dalam 
1064 Implementasi Model ASSURE Untuk Mengembangkan Desain Pembelajaran di Sekolah Dasar Rozie Iskandar, Farida F

DOI: https://doi.org/10.31004/basicedu.v4i4.468

proses pembelajaran. Desain pembelajaran yang dikembangkan tentunya harus memperhatikan beberapa hal yang menjadi acuan penting dalam proses pembelajaran. Diantaranya yaitu, penggunaan model pembelajaran. Model yang digunakan dalam mengembangkan desain pembelejaran yaitu model ASSURE. Model ini merupakan model yang mengikutsertakan teknologi dan media yang berkembang untuk memabntu guru baik dalam proses pembelajaran maupun dalam mengevaluasi pembelajaran itu sendiri.

Selain menggunakan model dalam pengembangan desain pembelajaran, guru juga menggunakan konsep pembelajaran tematik terpadu. Dimana pembelajaran tematik terpadu ini adalah pembelajaran yang mengaitkan beberapa bidang studi pelajaran kedalam satu tema yang mana materi antara bidang studi tersebut saling terkait.

Pengembangan desain pembelajaran dengan menggunakan model ASSURE dengan konsep pembelajaran tematik terpadu diharapkan mampu memberikan pengalaman yang berkesan bagi peserta didik, mampu mengembangkan pengetahuan peserta didik serta mampu meningkatkan hasil belajar peserta didik sesua dengan tujuan pembekajaran yang ingin dicapai oleg guru.

\section{REFERENSI}

Abidin, yunus. 2014. Desain sistem pembelajaaran dalam konteks kurikulum 2013. Jakarta. Refika Aditama

Afandi, Muhammad. 2011. Perencanaan pembelajaran di SD. Bandung. Alfabeta

Depdiknas. 2014. Implementasi Kurikulum 2013. Jakarta. Depdiknas
Emzim. 2011. Model Penelitian pendidikan dan pengembangan. Jakarta. Prenada media group

Farida, F., Zikri, A., Padang, U. N., \& Barat, S. (2020). PENINGKATAN SIKAP DAN KEMAMPUAN BERPIKIR ILMIAH SISWA MELALUI MODEL PBL DI SEKOLAH DASAR. Jurnal Basicedu Volume 4 Nomor 2 April 2020 Hal. 491- 497 JURNAL BASICEDU Research \& Learning in Elementary Education Https://jbasic.org/index.php/basicedu, 4(2), 491-497.

Hasanah. 2013. Desain Pembelajaran. Jakarta : prestasi Pustaka Raya

Hosnan. 2014. Pendekatan saintifik dan kontekual dalam pembelajaran abad 21. Bogor: Ghalia Indonesia

Iwantoro, Nur. 2016. Kompetensi pedagogik. Sidoarjo. Genta Group Produktion

Kemendikbud. 2016. Panduan penilaian untuk sekolah dasar. Jakarta. Keendikbud

Kemendikbud 2014. materi pelatihan guru implementasi keurikulum 2013 tahun 2014. Jakarta. Badan PSDMPK PMP

Lifda Sari, Taufina, F. F. (2020). Jurnal basicedu. Jurnal Basicedu Volume 4 Nomor 4 Tahun 2020 Halm. 813 - 820 JURNAL BASICEDU Research \& Learning in Elementary Education

Https://jbasic.org/index.php/basicedu/index, 4(4), 813-820. https://doi.org/10.31004/basicedu.v4i4.434

Majid, Abdul. 2014. Strategi Pembelajaran. Bandung. PT Remaja Rosda Karya

Mulyasa. 2014. Guru dalam implementasi kurikulum 2013. Bandung. Remaja Rosda Kaya

Nofriza Efendi,Yanti Fitria,Farida F, S. (2019). PEMBELAJARAN IPA MENGGUNAKAN PENDEKATAN SAINS TEKNOLOGI MASYARAKAT ( STM ) DI KELAS IV SEKOLAH DASAR. Jurnal Basicedu Volume 3 Nomor 3 Tahun 2019 Halaman 882-893 JURNAL BASICEDU Research \& 
1065 Implementasi Model ASSURE Untuk Mengembangkan Desain Pembelajaran di Sekolah Dasar Rozie Iskandar, Farida F

DOI: https://doi.org/10.31004/basicedu.v4i4.468

Learning in Elementary Education Https://jbasic.org/index.php/basicedu, 3, 882-893.

Putra, Nusa. 2013. Research and development, penelitian dan pengembangan suatu pengantar, Jakarta: Raja Grafindo Persada

Pribadi, A, Benny. 2010, Model desain sistem pembelajaran. Jakarta: Dian Rakyat

Sugiono. 2009. Model penelitian kuantitatif, kualitatif dan $R$ and $D$. Bandung: Alfabeta

Rohman, Muhammad. 2013. Strategi Desain pembelajaran Sistem Pemeblajaran. Jakarta: Prestasi Pustaka Raya

Riyanto. Yatim. 2014. Paradiga baru pembelajaran sebagai referensi bagi pendidik dalam implementasi pebelajaran yang efektif dan berkualitas. Jakarta. Kencana

Rahman, Muhmad. 2013. Strategi dan desain pengebangan sistem pembeljaran. Jakarta. Prestasi Pustaka Raya

Syarif, muhammad. 2016. strategi pembelajaran. Jakartaberorienasi standar proses pendidikan. Jakarata: kencana

Semiawan. Conny R. 2008. Catatan Kecil Tentang Penelitian dan pengembangan ilmu pengetahuan. Jakarta: Kencana Prenada Media Group

Sanjaya, wina. 2010. Strategi pembelajaran berorientasi standar proses pendidikan. Jakarta. Prenada media group

2011. Perencanaan dan desain sistem perencanaan. Jakarta. Prenada

Syafruddin. 2016. Kurikulum pembelajaran. Jakarta. Raja Grafindo

Sharon. 2011. Intructisional technology and media for learning. Jakarta: Kencana

Trianto. 2010. Pengantar penelitian pendidikan bagi penegmbangan profesi pendidikan dan tenaga kependidikan. Surabaya. Prenada Media Group
2011. Pengantar penelitian pendidikan bagi pengembangan profesi pendidikan dan tenaga kependidikan. Jakarta: Kencana Persada Media Group

Yamin. Martinis. 2007. Strategi pembelajaran Berbasis Kompetensi. Jakarta: GP Press Media Group 